\title{
The Modern Paradigm of Art and Its Frontiers
}

\author{
Gizela HORVÁTH \\ Department of Arts, Partium Christian University, Oradea, Romania \\ Email: horvath.gizela@partium.ro \\ ORCID: 0000-0002-7254-3704
}

\begin{abstract}
The awakening of art to self-awareness and the statement of its autonomy are modern phenomena.

The way we think about art in the modern age may be derived from the Kantian "beauty without concept". Beautiful art is the work of the genius, who creates a work of art that is valuable in itself and is admired in museums by the public. That which I call here "the modern paradigm of art" is based on an absence: the non-conceptuality of the beautiful, i.e., the fact that objective qualities cannot define the beautiful. This absence establishes originality as the essential requirement for modern art and creates the possibility for artists to push the boundaries of the modern paradigm. Thus, the 20thcentury sees the appearance of strategies for overriding or substituting originality. The artist withdraws from behind her work, and the work of art is no longer an unapproachable object with an aura, just as the museum is also no longer the temple of the arts. But do these experiments overcome the frontiers of art's modern paradigm? And, more generally, can this paradigm be overcome at all?

Here I deduct three elements of the modern paradigm of art from the idea of "beauty without concept": (1) the original artist, who is seen as a genius, (2) the work of art with an aura, and (3) the museum as the temple of art. Then I present how artists, based on the requirement of originality, worked on dismantling the frontiers of the modern paradigm.
\end{abstract}

Keywords: modern art, autonomy of art, originality, beauty without concept, genius

\section{The premodern idea of art}

Artistic phenomena are as old as humankind, but the concept of art is a product of the modern age. As Kristeller proves it in an excellent study,

the term 'Art,' with a capital A and in its modern sense, and the related term 'Fine Arts' (Beaux Arts) originated in all probability in the 18th-century" (Kristeller, 1951: 497).

But if the concept of art and the system of arts was born in the 18th-century, then what was there before it? How did people think about art? First, art was seen as being very close to the crafts. Generally, it was believed that the artist possesses a skill that he can impart to his disciples and can produce a useful object based on this knowledge. Second, artworks were created and valued not only for their beauty, but also for the sake of their representative function, as manifestations of religious, political, and economic power, or sometimes for their moral message. Third, artworks did not have a place of their own, built specially for their sake. One could find them in churches, palaces, or cabinets of curiosities. Before the 18th-century, the artist, the work of art, and the museum did not exist - at least not in the sense that we think of today.

As Kristeller proves it, the concept and the system of arts was born through sustained efforts. He considers Charles Batteux's study as decisive in this respect. In this text, the 18th-century French philosopher establishes that the arts deal with the beautiful (based on imitation), and constructs a system in which a specific place is allocated to each main branch of art. Kristeller concludes his essay with Kant, highlighting as his merit that

he was the first major philosopher who included aesthetics and the philosophical 
theory of the arts as an integral part of his system. (Kristeller, 1952: 42)

Kristeller does not emphasise here the radical turn that took place around Kant, which brought us a revolutionary new concept and practice of art. Kant did not only endow aesthetics with the same dignity as that of epistemology and ethics but also established the modern paradigm of art. Before this turn, "most of what we think of today as art was not created as art" (Gaie, 2017: 48).

\section{2. "Beauty without concept" and the modern paradigm of art}

In his "Analytic of Beauty", Kant deals with beauty as the object of judgements of taste, offering not a single, but four definitions of beauty, along with the four "moments" of aesthetic judgement. These show that beauty itself does not have a definition, as its pleasure is a matter of subjective judgement. That is to say, one cannot specify the objective characteristics of beauty, which could serve as its criteria. Thus, beauty is judged "without concept", along with the joint play of understanding and imagination, free from any emotional or intellectual coercion. However, since understanding and imagination, which are involved in the judgment of beauty, function within every human being and are general abilities of humans, the judgement on beauty is not arbitrary after all, but has a subjective generality. Kant then logically derives the space of the fine arts from this conception of beauty.

\subsection{The genius}

The artist who creates the fine arts cannot rely on rules or any definition of beauty. Consequently, he has no choice than to be original and to create without precedents. Therefore, "beautiful art is art of genius" (Kant, 2000: 186). The craftsman, who knows only how to apply learned rules, is "someone who, because he can never do more than merely learn and imitate, is called a blockhead" (Kant, 2000: 187). He cannot create fine art because he works based on rules derived from concepts, but beauty is without concept.

Nevertheless, "every art presupposes rules", and art itself cannot establish these rules without the concept of the beautiful. Therefore, the genius is needed, since he has "the talent (natural gift) that gives the rule to art" (Kant, 2000: 186). This is just what genius consists in. The artist creates without rules, and the rule he proposes is embodied in the work of art he produces. However, this is not a conscious and intentional rulemaking. The genius creates in the same way as nature: instinctively and without planning in advance, or being able to describe all the details of the creation process. And yet, the finished work gives the impression that there is nothing random about it, and everything is just at its place within it.

This is precisely why artistic genius is an inborn talent and cannot be transferred or taught. Some professional skills can be transmitted, but genius itself is not teachable. The artist produces works that can be followed as models, but not copied. If the student does everything in the same way as his master, he misses exactly what is essential: he will not be original, while, for the genius, "originality must be its primary characteristic" (Kant, 2000: 186).

The significance of these lines for future thought on art can hardly be overstated. The requirement of originality, so obvious for us that it could even be called the basic "aesthetic imperative" ("If you're an artist, be original!") was not a criterion before Kant. Up until him the novelty of an artistic approach was not essential. The fundamental issue was how well the artist managed to imitate nature and to represent his theme in a lifelike, or perhaps, passionate manner. This followed from the fact that art was considered imitation requiring technical skill. However, from now on, art becomes creation 'ex nihilo', requiring ingenium ('innate talent') - which, in turn, logically follows from the fact that beauty has no concept, and art is "beautiful" (or fine) art.

The image of the artist as genius is further nuanced in the context of romanticism and the avant-garde. In Schopenhauer (2010), the 
genius appears as a clumsy eccentric from the perspective of everyday life, but one whose sharp pure gaze sees and displays for us the world in a different manner. Kant and Schopenhauer agree that only the artist can be a true genius. The scientist only possesses the analytic knowledge, while the genius stands out among the "blockheads" with his peculiarity and originality.

The artistic genius in condemned by his outstanding talent to be ignored by his contemporaries, the "blockheads", who often stand perplexed in front of his works, and neither understand nor recognise him. As such, the genius artist creates for the future and expects recognition from posterity. The critic can no longer judge his work, but at most he can attempt to understand and mediate it for the public.

Art lacks any functional legitimatisation: beauty is without interest, valuable in itself, and art is autonomous. The artist creates from an inner need, and the work of art is judged according to purely aesthetic criteria.

\subsection{The work of art}

The requirement of originality and the conception of the artistic genius presented above also entailed the revaluation of the work of art and the birth of a new institution, the museum.

Hitherto, paintings and statues fulfilled a representational function. They were produced at request and were meant to demonstrate the personality, deeds, wealth, and taste of the patron. Furthermore, statues and paintings were about reality, and the criterion for their assessment was correspondence with, or similarity to, reality.

The work of the artistic genius does not have any external function anymore and cannot be evaluated solely by external criteria. The painting is no longer a "window on the world," as it was thought in the Renaissance. The artist's job is no longer to represent the visible. The genius artist is driven exclusively by an internal need for creation, and his creation expresses his internal world solely, or in other words, to return to Kant's formulations, its function is "the presentation of aesthetic ideas" (Kant, 2000: 192).

The work of art is not an object that can be created at any time and in any number of copies. A specific artist can only create a particular work of art, and only once. The artwork's originality and uniqueness is a consequence of its author's originality.

Hence, works of art are increasingly separated from everyday objects, and similarly to religious objects, their aura becomes more and more visible, as a "strange tissue of space and time: the unique apparition of a distance, however near it may be" (Benjamin 2008: 23). The transfiguration of artworks (Danto 1974) manifests itself primarily in the fact that we do not treat them as mere objects anymore, but almost as life forms, attributing to them bodily integrity otherwise characteristic only of living beings. For instance, we consider paintings to be organic wholes to which one cannot add and from which one cannot subtract anything even if we are speaking of a completely homogenous, monochrome painting. This was not at all the case even at the beginning of the 18th-century. In 1715, Rembrandt's famous Night Watch was cut on all sides to fit into the town hall in Amsterdam (thus even removing two characters from the painting). Nowadays, this would be considered an unimaginable act of vandalism. The aura of the artwork demands our unconditioned respect and reverence.

\subsection{The museum}

The newly born art object also needed a new home, where the public could approach it with admiration and respect. This temple of the arts is the museum, which has spread all across Europe also in the second half of the 18th"century. The expression "temple of the arts" is not coincidental: the museum collects, researches, and preserves for posterity highly valued artworks, protecting them from the damaging effects of time and exhibiting them in a separate space, illuminated and equipped with frames and labels for the visitors. Most classic museums resemble ancient Greek temples even visually. They are imposing 
buildings in which the stairs lead to an entrance framed by pillars and crowned with the tympanum. Exhibited artworks are usually protected by a security line from the visitors, who are prohibited from getting too close to them. Similarly to the temple, the museum is also a location for quiet meditation and finding ourselves, where one should not make any noise, run around, or laugh, but contemplate the artworks in respectful silence.

The museum further strengthens the autonomous conception of art, i.e., the impression that artists and artworks belong to a separate world, removed from our everyday life, which has its own rules and is not confined by the profane expectations of ordinary people.

So this is how the modern paradigm of the fine arts now stands before us in a tight formation, being composed of the artistic genius, the artwork with its aura, and the museum. The artist is not a craftsman anymore, but an inspired and original creator, just as the work of art is no longer an everyday object, but a complete, inviolable, and unique entity, and as the museum is also no more a privately owned and crowded cabinet of curiosities, but a building that is open to the public and an essentially public space for admiring art. This entire coherent conceptual apparatus can be derived from Kant's "beauty without concept".

The lack that is at the heart of beauty, which demands originality from the artist and commands him to impose his own rules on art, simultaneously also enables him to attack the frontiers of the modern art paradigm itself.

\section{The vertigo of originality}

The requirement of originality forces artists to become experimental. Thus, the art of the 20th-century mainly consists of artistic projects which call into question the paradigm sketched out above. The artist leaves the museum behind, the artwork's aura is battered, and the artist steps out from behind her work.

\subsection{Out of the museum}

The non-conceptuality of the beautiful introduces a conception of art according to which the artistic genius is always ahead of his time precisely due to his genius, creating artworks which are incomprehensible to his contemporaries and will only be valued by posterity. The autonomous art emphasised by modernism, or the conception of l'art pour l'art, will soon end in the elitist l'art pour l'artiste motto, as art loses its connection to the public, and the public is no longer really interested in art.

Some artists begin to work on closing this gap between artists and ordinary people, or between art and life. In their view, the museum is the antechamber to the death of art, where art objects become relics instead of our everyday nourishment. Therefore, they invent art forms, which relate critically and ironically to the museum or even exist outside it.

In the first category, we have artworks, which introduce everyday objects and common materials into the museum. One such example is Duchamp's Fountain, which, if introduced into the museum, threatens the seriousness of all other exhibited objects. This gesture is further intensified by Maurizio Cattelan's America (2016), a fully functional, solid 18-karat-gold toilet exhibited in New York's Guggenheim Museum - not on a pedestal, but in one of the smaller rooms, so it can be handy when needed. The second category contains, among others, performances and works of land art. Performances cannot be conserved in the first place. At most, one can exhibit their documentation in the museum. The performance has to be experienced in person. If we only encounter its documentation, it is as if one would hang a description of The Night Watch on the wall instead of the painting. Similarly, land art also cannot be brought into the museum. It is created in a place where theoretically everyone can see in without buying an entrance ticket, and only its documentation, such as photographs, videos, plans, and videos of land art can enter into the museum. Land art is dedicated not to 
the connoisseurs, but to everyone who passes by it.

Incidentally, these examples also show that the modern paradigm of art does not go down in gentle surrender. The museum and the art gallery did not crumble to dust under the impact of the Fountain but instead annexed it. Museums continue to collect documentation of performances, plans, and photographs of land art, and the public also continues to gaze at them behind the glass windows respectfully.

At the same time, the contemporary museum is evidently attempting to break out of its isolation, and functions as a kind of professional, cultural centre instead of a "temple of the arts", with museumpedagogical programs and community projects.

\subsection{Against the artwork}

The $19^{\text {th }}$-century artwork was a specific object (e.g. a painting, a statue, a drawing, or a relief, etc.). Later, the originality of the artist will also manifest itself in the fact that artworks, which are difficult to identify are becoming increasingly prevalent since the second part of the 20th-century.

On the one hand, we have art forms not embodied in objects, but nevertheless belonging to the field of the visual arts, e.g. performances, happenings, the "social sculptures" of Beuys, and Fluxus events. The situation becomes even more complicated towards the end of the 20th-century and during the first years of our century with the phenomena of relational art. Tobias Rehberger's cafeteria at the Venice Biennale, with its delicious espressos and croissants, is not also an artwork at first sight. In Rirkrit Tiravanijat's hidden rooftop teahouse, at Singapore's National Gallery, one can have real tea and even participate in a tea ceremony, though it is uncertain whether this is art at all.

On the other hand, within the world of objects, our ideas about paintings and sculptures are also changing, as the boundaries of art are continuously expanded.
At the middle of the 19th-century, it was scandalous for Courbet to depict stonebreakers (because of the vulgarity of the theme), and Picasso's Les Demoiselles d'Avignon also provoked shock (due both to the vulgarity of the theme and the unusual presentation) at the beginning of the $20^{\text {th }}$ century. But even as their value was debated, at least it was clear that they were paintings. Later, however, already with Picasso, "neither painting nor sculpture" art objects begin to appear, transcending the usual boundaries between these categories of artworks. Artists started to create pieces about which it was unclear at first sight whether they were artworks at all. Duchamp's snow shovel (Prelude to a Broken Arm) is perceptually identical to an ordinary snow shovel. Thus, the "christening" of the art world is needed for it to become an artwork (Danto, 1974). Andy Warhol's Brillo Box is also perceptually almost identical to the Brillo boxes lying on supermarket shelves. This specific work will be the one to inspire Arthur C. Danto's art philosophical reflection on what it is that differentiates art objects from ordinary ones. It is a question that can only be asked because artists who create based on the requirement of originality can sometimes produce artworks which are not evidently artworks at all.

Finally, I would also like to mention here those artworks which consciously seek to destroy the aura of art. For instance, Duchamp's LHOOQ targets the most famous work in art history, the Mona Lisa of Leonardo da Vinci. With noble simplicity, Duchamp has drawn a discrete moustache and a goatee to Mona Lisa and renamed the image with an anagram with a vulgar meaning in French. This is not only an early example of appropriation art but also a malicious and cynical appropriation. Duchamp ridicules here the so-called "retinal art", which proclaims the sanctity of the artwork, seeks to delight the eye, and is thoroughly humourless. The masterpiece of the greatest Renaissance master is unseated from the throne and thrown into the context of disrespectful and rude jokes.

Piero Manzoni's strategy is diametrically 
opposed to Duchamp's. He lifts the vulgar to the level of the sanctified artwork, thus damaging its aura. In 1961, he created 90 small tin cans, sealed with the text "Merda d'artista" ("Artist's Shit"), which supposedly each contain 30 grams of the substance mentioned in the title. Manzoni priced his tin cans at 37 dollars, equalising each gram of their content with 1 gram of gold. The work of this artist, who died at a young age, was soon bought by collectors, at a much steeper price than gold. 182,500 pounds were paid for a can at Christie's in 2015, and another one went for 275,000 Euros in Milan in 2016. Manzoni's tin cans are interpreted as a parody of the market, or as a critique of consumerism and the waste generated by it. However, the artist's correspondence reveals that the critique of the fetishisation of art also played a role here: if the collectors value the artist's touch so much, then let the artist give them a truly personal and direct product. Of course, we still do not know what the tin cans contain. If someone would open a can, this irreplaceable artwork, now worth several hundred thousand dollars, would be destroyed. Here the artist's gesture is a radical one, and at once cynical and witty, since the secret sealed in the box increases its attraction.

Manzoni literally asks us the question: are we really willing to accept any shit as art? And the answer based on the modern paradigm of art is a resounding yes - if the artistic genius produces and presents it to us as art.

\subsection{The genius against himself}

Art is, in its modern paradigm, the art of the genius. In other words, we have art if the work is produced through the natural and non-transferable talent of the creative genius. At the same time, due to the nonconceptual character of beauty, the genius has no choice but to be original and thus should not recognise any external constraints. He can paint cubist or abstract canvases, create installations, or build a bridge from the mainland to an island (Christo: The Floating Piers, 2016, on Lake Iseo) - in fact, the genius can do anything, since he is the one who imposes the rules in art, but with a caveat. Namely, ,that since there can also be original nonsense, its products must at the same time be models, i.e., exemplary" (Kant, 2000, 186). Now, whether a specific creation is nonsense or exemplary is decided by the attitude of the art world.

But can the artist even renounce creation itself, based on the requirement of originality? And can he call into question the basic requirement, i.e., originality? In this paradigm, the answer is yes, if he does it originally.

During the past century, artists have worked out several resourceful strategies to undermine the concept of the original and exceptionally talented creator itself. Here, I would like to highlight among them the case of the ready-made, followed by ephemeral and interactive works, appropriation strategies, and relational art.

The ready-made is almost the diametrical opposite of the chef d'oeuvre created by the artistic genius. It is not made by the hand of the artist and does not carry his touch. Moreover, it is not even an original product, but a mass-produced object. Nevertheless, the concept itself of the ready-made is radically original, with the questioning of "retinal painting", the highlighting of an everyday object in order to demonstrate the possibility of an art that is independent of aesthetics, and the witty titles - i.e., all the elements elevated by Duchamp as "cerebral dexterity" in place of "manual dexterity".

In the case of ephemeral works of art, the artist gives up on the complete and finished work, and builds on her work the corrosive effect of time. Thus, it is impossible to establish which one the final form of the artwork is. Generally, we expect from the artistic genius to create fully enclosed, complete, and durable works of art. Relying themselves on the requirement of originality, artists renounce this possibility for creating states that can only be imagined, but not determined in advance by them. This is the case, for instance, of Urs Fischer's Untitled, whose greatness stems precisely from its continuous decay. For the 2011 Venice Biennale, he brought an installation 
occupying an entire room, with the life-sized and lifelike replica of the 16th-century sculptor Giambologna's Rape of the Sabine Women at its centre. The statue functioned as a giant candle whose wick was lit at the opening ceremony, to slowly but surely melt the beautifully carved statue of Giambologna. This ephemeral work brings the devastating effect of time closer to us through the example of the artwork supposedly created for eternity.

In the case of interactive works, the artist shares the joy and the responsibility of creation with the public by producing situations or objects which are only completed through the activity of the recipient. This was the case with \#Jan25 (\#Sidibouzid, \#Feb12, \#Feb14, \#Feb17...), presented by the artist collective Norma Jeane, also at the 2011 Venice Biennale. This block of coloured tri-tone plasticine, reminiscent of the Egyptian flag (black, white and red), was titled after the most popular Twitter hashtags used to inform and involve people across the world during the Arab revolutions. The members of the collective invited the visitors to use the plasticine cube as they wish in the spirit of the freedom of expression. Soon, the entire room was filled with forms and texts in these three colours, demonstrating the playfulness and creativity of the recipients. Certainly, the freedom of expression is not without its dangers. The artists could not foresee how the visitors will use their plasticine, and the wall could also have been filled with hate speech or obscene messages. Nevertheless, the freedom of expression represents a value, which is worth the risk. After all, the public enthusiastically collaborated on completing the artwork.

As for the procedures of artistic appropriation, their first forms consisted of using objects outside of the aesthetic realm. In this sense, the collages of Picasso and Braque, or Duchamp's ready-mades were also based on appropriation. Later, pop art appropriated the objects of mass culture, from Warhol's Brillo boxes to the popular genre of the comics (Roy Lichtenstein). In the $80 \mathrm{~s}$, artists began to appropriate entire artworks (Sherry Levine, Elaine Sturtevant), genres (Cindy Sherman), and styles of individual creations (Yasumasa Morimura). It is also an appropriation strategy for artists to exhibit collections along with, or instead of, their own work. At the 2009 Venice Biennale, the Nordic and Danish Pavilions presented Michael Elmgreen's and Ingar Dragset's The Collectors, offering two narratives, one of the murdered gay writer and the other one of the wealthy family forced to sell their home. Elmgreen and Dragset were both creators and curators of this work since they invited 24 further individual artists and artist collectives to contribute to their project. It was especially interesting to encounter here Elaine Sturtevant's work, which copied the black canvas of Frank Stella, as an appropriation's appropriation.

Nicolas Bourriaud subsumes the various appropriation procedures under the concept of "postproduction":

Notions of originality (being at the origin of) and even of creation (making something from nothing) are slowly blurred in this new cultural landscape marked by the twin figures of the DJ and the programmer, both of whom have the task of selecting cultural objects and inserting them into new contexts. (Bourriaud, 2005: 13).

$\mathrm{He}$ also offered the first discussion of relational art in his Relational Aesthetics (2002), providing an interpretive frame for artworks, which are not, objects, but "a state of encounter" (Bourriaud, 2002: 18). It is the requirement of originality alone that makes it possible, e.g., for Rirkrit Tiravanija to prepare curry for the gallery visitors, not as a culinary but a fine artist. In most cases of relational art, the artist only provides a framework for the members of the public to act and establish relationships between themselves. However, there are also relational works of art, which do not create new relationships but question our existing human relations. Santiago Sierra's works fall into this latter category. He usually invites people to perform demeaning tasks for a minimum amount of pay. In one of his works, he paid participants to let a line be tattooed on their backs. In 2001, for his work entitled 133 persons paid to have their hair dyed blonde, he asked emigrants struggling in Venice and African people involved in an illegal trade to change 
their hair colour. Suddenly, black skinned people with shining blonde hair began to stand out on Venice's narrow streets and bridges, and their presence involving uncomfortable questions could not be ignored anymore. Sierra himself does not tattoo or dye people's hair. He only invents the framework which will highlight how human relationships function under capitalism.

\section{Where are the frontiers?}

As we have seen, the modern paradigm of art can be derived from Kant's ideas on nonconceptual beauty. If beauty lacks concepts, i.e., cannot be defined by objective characteristics, then the fine arts must also lack rules of production and objective evaluation criteria. The artistic genius is the one who has to impose the rules on art, and his most important quality is originality. There is a necessary logical implication between the idea of non-conceptual beauty and the requirement of originality.

This is the starting point for the way in which we have been seeing art for over two centuries: based on their exceptionalinborn talent, artistic geniuses create artworks which we admire in museums. At the same time, this is also the condition for the possibility for free creation that is enjoyed by artists, who can even experiment with the deconstruction of this paradigm, while being firmly established on its very basis. However, as also seen above, these experiments remain within the modern paradigm of art. The pillars of the modern paradigm do not crumble but are redefined, as the meaning of originality, creation, artwork, and museum is continuously rewritten.

Can the modern paradigm of art be overcome? I guess that it cannot, as long as art is fine art, and originality remains the categorical imperative of art. If the artist has to be original, then originality can even entail its own questioning - as long as it is done originally.

The overcoming of the paradigm could be conceived as the reestablishment of an already transcended state. In this case, art would not be considered valuable in itself, but serve an outside purpose. Furthermore, the artist would not need to be original, but to know his (or her) craft. This would mean that we have come to the end of the age in which art considered itself to be autonomous. But I do not see how we could leave the modern paradigm of art behind us and also preserve the autonomy of art.

Nevertheless, one should not forget that art is the most creative of human pursuits. As such, it can still surprise us with unforeseeable practical solutions and theoretical assumptions. It would be indeed beautiful.

\section{Bibliographical references}

Benjamin, Walter. (2008) The Work of Art in the Age of Its Technological Reproducibility: Second Version. Cambridge London: The Belknap Press of Harvard University Press

Bourriaud, Nicolas. (2005) Postproduction. Culture as Screenplay: How Art Reprograms The WORLD. New York: Lukas \& Sternberg.

Bourriaud, Nicolas. (2002) Relational Aesthetics. Dijon: Les presses du réel.

Danto, Arthur C. (1974) The Transfiguration of the Commonplace. The Journal of Aesthetics and Art Criticism, 33(2), 139-148.

Gaie, Ștefan. (2017) Arta. O introducere. Cluj: Presa Universitară Clujeană.

Kant, Immanuel. (2000) Critique of the power of judgment. New York: Cambridge University Press.

Kristeller, Paul Oskar. (1951) The Modern System of the Arts. A Study in the History of Aesthetics. Part I*. Journal of the History of Ideas 12(4), 496-527.

-----. (1952) The Modern System of the Arts. A Study in the History of Aesthetics. Part II. Journal of the History of Ideas 13(1), 17-46.

Schopenhauer, Arthur. (2010) The world as will and representation. New York: Cambridge University Press. 